\title{
The economic impact of peacekeeping. Evidence from South Sudan
}

\author{
Raul Caruso* \\ Prabin Khadka§ \\ Ilaria Petrarca ${ }^{\dagger}$ \\ Roberto Ricciuti ${ }^{\ddagger}$
}

\begin{abstract}
This paper investigates the effect of the deployment of United Nations Blue Helmets on economic activity in South Sudan with a special focus on agricultural production Since UN troops are predicted to improve security, in particular, we expect a positive relationship between deployment of UN blue Helmets and cereal production. We test our hypothesis using an original dataset including all the 78 South Sudanese counties over the period 2009-2011. We control for the non-random assignment of UN troops through an Instrumental Variables approach. Our empirical results show that a 10\% increase in the size of the troop allows the production of additional 600 tonnes.
\end{abstract}

Keywords: Peacekeeping, United Nations, Blue helmets, South Sudan, cereal production, security.

JEL Codes: C26; D74; F53; H56

\footnotetext{
* Corresponding author. Institute of Economic Policy - Center for Applied Economics (CSEA) Università Cattolica del sacro cuore, via Necchi 5, 20123, Milano. e-mail: raul.caruso@unicatt.it

$\S$ Departments of Politics, New York University

$\dagger$ Department of Economics, University of Verona

$¥$ Department of Economics, University of Verona and CESifo

Acknowledgements. Earlier versions of this paper have been presented at the 2012 Workshop on the Economics of Conflicts at the Catholic University of the Sacred Heart, Milan, the 2013 Summer School in Development Economics, at the University of Verona, the 2013 Meeting of the Italian Economists Society held at the University of Bologna, and the Development@Manchester Seminar Series. Financial support from the University of Verona is gratefully acknowledged.
} 


\section{Introduction}

Peacekeeping is an international public good whose benefits are supposed to accrue to a variety of actors (Morrissey et al., 2002). At national level, peacekeeping is expected to provide the most relevant benefits because of enhanced security for local population. In addition it must be considered that peacekeeping - by decreasing insecurity - provides benefits also to regional neighbourhoods and to the whole world community (Sandler, 2002). The aim of this paper is to study the national benefits, namely the economic impact of peacekeeping on local economy. In particular, this paper focuses on the impact of peacekeeping on agricultural production in South Sudan.

South Sudan is the newest country in the World, established on 9 July, 2011. Independence was affirmed after a referendum held in January 2011, which declared secession from Sudan. In the last sixty years they fought two civil wars, the first one from 1955 through 1972 and the second one from 1983 through 2005. Nowadays, they are still involved in skirmishes along the border caused by land claims. In December 2013, a political power struggle broke out between President Salva Kiir and his ex-deputy Riek Machar, accused of attempting a coup d'état. This led to a sectarian conflict, with rebels targeting members of Mr Kiir's Dinka ethnic group and government soldiers attacking Nuers. ${ }^{1}$ Needless to say, violence interplays with technological underdevelopment, thwarting South Sudan's progress. Insecurity discourages the economic activity and has a negative impact on agricultural production. In 2005 the United Nations started a peacekeeping mission in South Sudan, named UNMIS, and since then Blue Helmets have been in the country. The primary goal of UN troops is to enforce peace among fighting groups. In addition, this may also be expected to have a benign impact on productive activities. In fact, a

\footnotetext{
1 Up to 10,000 people are estimated to have been killed in the inter-ethnic Dinka-Nuer fighting, more than 1,000,000 people have been displaced inside South Sudan and more than 400,000 people have fled to neighboring countries. On 27 May 2014, the Security Council unanimously adopted resolution 2155 (2014) to reprioritize the mandate of UNMISS towards the protection of civilians, human rights monitoring and support for the delivery of humanitarian assistance, and increased the Mission's troop strength to 12,500 and a police component to up to 1,323 personnel.
} 
lower degree of conflict is expected to entail the possibility of restarting production and investment. The question we address in this paper is: do really UN troops have a beneficial impact on agricultural production? In particular, do UN troops secure crops in South Sudan? South Sudan is a suitable testing ground for our study, because it has been largely reported that the enduring conflict depressed its agricultural performance (World Bank, 2013). From a geo-morphological point of view, the country is divided into six agro-ecological zones offering a diversity of agricultural potential (maize, sorghum, wheat, and so on), abundance of water resources as rainfall, lakes and rivers. Despite this potential, the cereal production seldom meets the demand. The poor quality of productive inputs and support services, the low and inefficient technology, and eventually the lack of infrastructure constitute a severe limit to production and contribute to reduce the yield.

Furthermore, it has been often reported that militia attacks often destroy the crop and the livestock. Farming households are therefore discouraged because of the widespread insecurity and cultivate only the land close to their home (Johnson, 2011). Only less than 5\% than the 30 million hectares of arable land in the country is harvested. In fact, more than a third of South Sudanese in 2010 suffered from moderately or severely food insecurity; among them, severe child acute malnutrition is about 13\% (World Bank,2013). The fiscal revenues of South Sudanese government almost totally depend on oil royalties (98\%), thus making the state capacity interdependent with international oil prices, which are volatile. Outside the oil sector, livelihoods are concentrated in low productive, unpaid agriculture and pastoralists work, accounting for $15 \%$ of GDP. In fact, $85 \%$ of the working population is engaged in non-wage work, mainly in agriculture (78\%). The per capita GDP in 2013 was $\$ 1,085$. The economy is strongly dependent from aid: from 2007 to 2013 donors' commitments have totalled about $\$ 4.5$ billion, excluding $\$ 4$ billion in contributions to UNMISS peacekeeping for the same period (World Bank, 2013).

In this paper we empirically analyze the relationship between the deployment of United Nations Blue Helmets in South Sudan and cereal production in order to 
uncover a relation between these variables. The issue has not been tackled so far in the literature, and it is not a trivial one. First, Blue Helmets are expected to positively affect agricultural production, as their formal mission is 'consolidate peace and security' (art. 3 UN Resolution 1996, 2011). The channels through which a beneficial impact is predictable are: (i) a enhanced feeling of security; (ii) a direct demand of tradable goods and foodstuff of UN personnel.

The provision of security should induce workers to exert more effort in agricultural production because lower conflict reduces the risk of expropriation and the makes the act of going in the field less perilous for the worker itself. Once deployed in the country, however, Blue Helmets are also expected to purchase consumer goods so fuelling the local demand and eventually increasing the actual sales prices of many primary goods.

An additional aspect is crucial. The UN troops' deployment may be nonrandom. The assignment of Blue Helmets to counties' headquarters reasonably follows a rationale. For example, the troops are sent where the largest number of conflict-related incidents had taken place. ${ }^{2}$ Alternatively, those areas where infrastructures are more developed and it is easier to get food are preferred to more peripheral and desolate counties. If the deployment scheme implemented is correlated with the output variable, i.e. cereal production, our estimates will be biased. To consider this issue we employ an Instrumental Variable approach, finding valid instruments for the size of the troop.

The results of the estimates support our hypothesis: there exists a significant relationship between the deployment of UN troops and cereal production, and it is positive. The estimated marginal effect, robust to alternative specifications of the model, is about $+0.6 \%$.

The rest of the paper is structured as follows: Section 2 reviews the small literature on the effects of peacekeeping, whereas Section 3 describes the history of

2 Gledistch and Beardsley (2014) show how peacekeepers are able to contain conflict in specific wartorn subnational areas. 
South Sudan and the UN mandate for peacekeeping. Section 4 introduces the empirical specification and the data; in Section 5 results are presented, and Section 6 concludes.

\section{The economic effects of peacekeeping interventions}

Although the economic analysis of peacekeeping is a developed field of research (for overviews see Solomon (2007), Bove and Smith (2011) and Dorussen (2014)), the issue of the economic effects of peacekeeping is in its infancy. In fact, the economic analysis of peacekeeping mainly deals with the following issues: (a) the demand side of peacekeeping operations (the conflict situations that invite peacekeeping interventions), (b) the supply peacekeeping (namely the willingness and incentives of a country to participate into a $\mathrm{PKO}$ ), (c) the outcome of peacekeeping operations; (d) the cost of peacekeeping operations. In particular, pioneering discussions on the costs of peacekeeping are in Arrow (1994) and in Klein and Marwah (1996). Evidence on burden sharing is provided in Shimizu and Sandler (2003), suggesting that peacekeeping has a relatively large share of purely public benefits, leading to some 'exploitation of the large by the small'. Jyoti et al. (1999) first studied the determinants of UN peacekeeping contributions for the period 19751996.Gaibullovev et al. (2009) analyze the determinants of UN and non-UN peacekeeping interventions. Bove (2011) and Bove and Elia (2011) study the supply side of peacekeeping. All these articles empirically show that specific characteristics of participating countries explain the supply of peacekeeping especially in non-UN operations. Put differently, potential gains of participating countries matter more than potential benefits of war-torn areas. On the size of UN missions, Ruggeri et al. (2013) find a size effect, namely rebel groups and local governments are more willing to cooperate with larger UN missions.

As noted above, less attention has been paid to the impact of peacekeeping on economic development and sustainability of countries when deployment of troops has taken place. The economic impact of peacekeeping ought to be, in fact, the study 
of how war-torn economies can be restored to their capacity of stimulating economic development thanks to security spillover generated after the peacekeeping has taken place. This appears to be particularly appropriate when taking into account that modern peacekeeping is multidimensional (Dorussen and Gizelis, 2013).

In fact, peacekeeping is a public good whose benefits accrue to a variety of actors. First there are some localized benefits that are directly linked to the conceptual framework envisioned in Brauer and Caruso (2013). Peacekeeping should be first expected to: (1) provide a security spillover that would enhance incentives of entrepreneurs and laborers to be involved into an ordinary economic activity rather than in appropriation activities; (2) involve also economic policies able to contribute to the economic reconstruction of the violence-afflicted country. In this respect the economic study of peacekeeping falls within the domain of peace economics as defined in Isard (1994), Tinbergen (1994), Arrow (1995), and Caruso (2010).

The first issue is linked with development economics that emphasizes the role of property rights in shaping the incentives for investments and therefore increasing income. Since the seminal work by North (1991), the relevance of institutions securing effective property rights is now unchallenged. Besley and Gathak (2009) show the role of property rights in reducing the risk of expropriation and that insecure property rights act as a barrier to trade reducing related gains. Avinash Dixit (2009), in his Presidential Address at the American Economic Association, claims that economic governance is important for markets and economic activity, and it provides three essential prerequisites for them: security of property rights, enforcement of contracts and collective action. Peacekeeping in fact is also related to this strand of literature. In fact, by increasing security peacekeeping contributes to enhance state capacity ${ }^{3}$ and provide a working system of property rights. It may represent a point of departure for enabling the country to address the social and

\footnotetext{
${ }^{3}$ Chowdury and Murshed (2013) show that disruption of state capacity in wartorn societies.
} 
economic problems which are pervasive in both war torn societies. ... In this respect the nature of public good is clear-cut. In fact, most of the features discussed above show non-rival and non-excludable characteristics. In particular, whenever peacekeeping turns to be successful, it contributes to generate an institutional setting which eventually may turn to be foster economic development in the long run.

To the best of our knowledge only a few studies have been published on this aspect of peacekeeping. Carnahan et al. (2006) claim that United Nations missions do more good than harm, in economic terms, than is commonly believed because there is an immediate upsurge in economic activity associated with the restoration of basic security. More directly, less than 10 percent of mission spending goes directly into the local economy, and 20 percent of mission procurement goes into the local economy. Instead, the perception of widespread inflation is not borne out, although some price rises occur in parts of the economy servicing internationals, and wages for scarce skilled labor increase. In fact, there are five areas where the ways in which the United Nations operates have negative consequences for the development of local economies: (1) the host government's revenue administration and the integrity of the revenue system is undermined by the way in which the United Nations Convention on Privileges and Immunities is applied; (2) the way in which a mission operates can establish expectations for both professional working environments and personal living standards that cannot be affordably sustained by a developing country; (3) missions make policy decisions without understanding the broader impact on the local economy; (4) the planning horizons with which the mission operates often lead to inefficient capital investment choices and increased costs for the host government after the mission leaves; (5) there is uneven distribution of economic impact by geographic area and ethnic group.

Related to the topic is the paper by Amara (2012) that considers the stabilization of Iraq, which - strictly speaking - is not a form of peacekeeping. The United States used a combination of economic, political, and mainly military means 
(the "surge", an increase in 30,000 troops to about160,000) to stabilize Iraq. Amara uses structural change tests to determine the effect of the intervention on security and economic metrics of success. There is little evidence suggesting that the surge was the primary intervention that enhanced economic development and political order.

In what follows we aim to contribute to this niche literature by providing empirical evidence on the impact of UN peacekeeping operations in South Sudan on agricultural production.

\section{Peacekeeping in South Sudan}

The United Nations Mission in Sudan (UNMIS) was deployed in 2005 after the signing of the Comprehensive Peace Agreement (CPA) between the Government of Sudan and the Sudan People's Liberation Movement (SPLM), ${ }^{4}$ ending more than 20 years of war. The Naivasha Agreement established South Sudan as an autonomous region of Sudan, and the mandate of the CPA consisted of four main issues: implementation of ceasefire between North and South Sudan; facilitation of the delivery of humanitarian aid; assistance to demining, and protection of civilians and human rights, including a safe return of internally displaced peoples and refugees. ${ }^{5}$ The military strength of UNMIS comprised of approximately 10,000 peacekeepers. The mission was decentralised in terms of its deployment locations and management structures. The strategic headquarters were based in Khartoum. The majority of staff (about 6,000 people) was deployed across the 10 States of South Sudan, including the county level as required (United Nations, 2011a). Table A.1 in the Appendix illustrates the administrative division of the country.

The peace process stopped in 2009, when tensions between the ruling National Congress Party and the SLPM accompanied a wave of armed violence. Tribal conflict affected mainly the Jonglei and Upper Nile states. The Government

4 On the evolution of SPLM see Metelis (2004).

5 See Security Council Resolution 1590. 
of South Sudan has been unable to restore security, and the politicization of the violence increased (McEvoy and LeBrun, 2010). The timing of the incidents followed the electoral timing: the executive elections in April 2010 have been preceded by tribal violence in Jonglei, Lakes, Upper Nile and Warrap states. Isolated cases of post-election violence were limited to a few states, such as Jonglei and Unity (CIGI Security Reform Monitor, 4/2011). The SPLM has been accused of undue influence for having mobilized security organs, including the army, to intimidate candidates. In this confused scenario several armed groups emerged (the Lord Resistance Army, the Joint Integrated Units, and others) and exerted pressure on the government. In January 2011 the independence of South Sudan was formalized with a referendum that obtained almost unanimous agreement: more than $98 \%$ of the voters choose to create a new state, separated from Sudan. On 9th July, after the culmination of a six-year peace process, South Sudan finally became a new country.

Khartoum's government, once accepted the independence of South Sudan, withdrew its consent for UNMIS to continue. At the same time, the mission turned into the United Nations Mission in the Republic of South Sudan (UNMISS), with the adoption of resolution 1996(2011). ${ }^{6}$ The Security Council authorized 7,000 military and a 900 civilian police personnel force for UNMISS, now headquartered in Juba, from contributing countries such as India, China, Bangladesh, Kenya and Russia which were divided into three sectors I-III7; each sector having the same area of responsibility as it did during UNMIS.

UNMISS's mandate is to "support the Government of the Republic of South Sudan in exercising its responsibilities for conflict prevention, mitigation, and resolution and protect civilians". 8 The UNMISS peacekeepers, therefore, have been entrusted with two distinct responsibilities - firstly to consolidate peace in the

\footnotetext{
${ }^{6}$ United Nations (2011b).

${ }^{7}$ Sector III seems to be the most high risk area in terms of threats. Sector III has three active RMG (rebel militia groups). RMG Mattew Pul Jang in Unity, RMG Ogat and Olony in Upper Nile and South Sudan Democratic Movement (SSDM) under Lt Gen Chol Awan in Jonglei (UNMISS, 2011b).

8 For details on UNMISS mandates, see official UNMISS (2011a).
} 
nascent state as a pre-requisite for state building and economic development, and secondly to assist government authorities in exercising their responsibilities to prevent and mitigate armed conflict and protect civilians (William, 2011: 8). The Southern Sudanese government initially objected to a Chapter VII mandate, allowing UNMISS to undertake operations to protect civilians, because the government wanted the UN to focus more on the problems lying with the contested northern border rather than internal security problems. Nonetheless, conflict between South Sudanese groups is strong, yielding to some 2,500 killings and the displacement of 350,000 people (Mc Evoy and LeBrun, 2010). Moreover, security provided by the blue helmets is critical to long-term stability and economic development, not least because of the vast agricultural plains but also because of natural resources of oil, agricultural land, water, Gum Arabic, and minerals (Arenas-Garcia, 2010: 5).

Figure 1 maps the diffusion of Blue helmets in the country. UN troops are located in only fourteen counties over 78, and their deployment does not follow any clear spatial pattern. The Blue Helmets are both in the north (e.g. Melut) and in the south (e.g. Yei), in large counties (e.g. Raga) and in smaller ones (e.g. Rumbek Centre), in coastal (e.g. Yambio) and internal areas (e.g. Bor South).

[Figure 1 about here]

Figure 2 provides details on the size of the county troops and their evolution in time. First, one must note that the deployment of Blue Helmets in a country is a permanent policy: during the period 2007-2011 we do not observe changes in the deployment of the troops. This is an expected pattern, because once the headquarter is established, it is costly to remove it or move it somewhere else; fixed costs, communication networks and infrastructures contribute to reduce the mobility of the troops. The largest share of the Blue Helmets is deployed in the three regional capitals: Juba, which is also the national capital, Wau and Malakal. At the same 
time, we do not observe any diffusion of the presence of troops across counties, and their size is quite stable. The only significant variation is observed in the last two years, when a reorganization of the troops occurred. Figure 2 indicates a reduction of Blue Helmets in some counties (e.g. Wau and Malakal) counterbalanced by an increase in others counties (e.g. Raja and Bor South). A plausible motivation for this reshuffle is that rising violence was expected in 2011, due to the approaching of the referendum. Instead of establishing new headquarters, it seems that the command rationalized the composition of the troops.

[Figure 2 about here]

\section{The dataset and the model}

This work exploits an original dataset consisting of all the 78 counties of South Sudan. For the purpose of estimating a cereal production function, we collected data from institutional sources (e.g. National Bureau of Statistics) and international organizations (e.g. OCHA in Juba). All these information compose an unbalanced panel dataset for the period 2007-2011, made of 390 observations. The variables included refer to demographic, socio-economic and geographical characteristics of the country, beside the already mentioned information on the location and the size of UN troops.

Our dependent variable is the net cereal production measured in tonnes (Cereal). The data is calculated by the South Sudan National Bureau of Statistics (NBS) for the years 2008-2011 and it is available at the county level. The explanatory variables refer to the input of the production. First, we include the surface of the harvested land (Total cereal area), measured in hectares. The source is again NBS Statistical Yearbook. We expect that the wider is the cultivated area, the greater is the output we observe. Unfortunately, information on the amount of physical capital and fertilizers is not available, but it seems they play a marginal role in agricultural production. FAO/WFP (2012: 9) reports that "farmers commonly 
use their own seed saved from the previous year's harvest, and virtually no commercial fertilizers, pesticides or herbicides are used". Technology is highly underdeveloped and all operations from sowing to harvesting are done manually. Land preparation exploits some mechanized processes, but the dominance of very low skilled workers prevents the introduction of advanced tools as modern ploughs. Therefore, the second main input for cereal production is human labor. Since smallholder farming dominates agricultural sector in South Sudan (Oakland Institute, 2011), we include Population and the Surface area of each county. We expect that, ceteris paribus, larger counties are able to produce a larger amount of output. Nonetheless, the soil is a good subject to rivalry in consumption, and when the population's density increases, congestion and excessive exploitation could reduce the yield. Finally, Rainfall is included in the specification, as drought threatens the crops in South Sudan. We introduced also the square term of rainfall, because non linearity better fits the climatic variables (Hsiang, 2013).

A key assumption of our analysis is that security affects productivity. To illustrate this point we consider two farming households, $\mathrm{H} 1$ and $\mathrm{H} 2$, endowed with two identical pieces of land, the same skills, the same ploughs and the same fertilizers. If $\mathrm{H} 1$ experiences a shock to the security of his piece of land, his output decreases. The reduction could be either direct (as an example a militia attack that destroys part of the crops), or indirect (cattle raids, physical violence and destruction of the ploughs that discourage the farming activity). Following this line of reasoning, conflict-reducing devices as the deployment of UN troops should reduce the security gap between $\mathrm{H} 1$ and $\mathrm{H} 2$, constraining the detrimental impact of the conflict on the agricultural production. This effect is captured by our variable of interest, Blue Helmets, which measures the number of UN soldiers headquartered in a county. Finally, we include some control variables: a dummy indicating the presence of a 
dominating ethnic group in the county ${ }^{9}$ (Ethnicity), the presence of the Dinka ethnic group dummy (Dinka), civil-war related killings per thousands of individuals (Killings). Table 1 summarizes data description and sources, whereas Table 2 provides summary statistics.

[Table 1 about here]

[Table 2 about here]

Then, we estimate the following model:

$$
\text { [1] } \text { Cereal }_{i t}=\alpha_{1}+\alpha_{2} \text { Blue Helmets }_{i t}+\alpha_{3} \mathbf{X}_{i t}+\mu_{i}+\theta_{t}+\varepsilon_{i t}
$$

where the subscript $i=1, \ldots, 78$ indicates the county, $t=2008, \ldots ., 2011$ indicates the year, $\mathbf{X}_{i t}$ is the vector of control variables, $\mu_{i}$ are county effects, $\theta_{t}$ are year effects and $\mathcal{E}_{i t}$ is a random error.

We suspect that the troops deployment is non-randomly chosen, therefore Blue Helmets induces endogeneity in the specification. We tackle this issue by estimating an Instrumental Variable model. In particular, we exploit two instruments for Blue Helmets. The first one is Roads, a proxy for the feasibility of the settlement; in fact, the presence of communication networks guarantees the possibility to provide primary goods to the headquarters, and make them easily reachable. The presence of roads is not a trivial issue in South Sudan, in fact OCHA reports that many countries are not connected through main roads, while the capital Juba is connected by only four main roads. ${ }^{10}$ The second instrument we employ is an

\footnotetext{
9 Dinka is the dominant ethnic group in South Sudan, we experimented with a dummy equal to one when this group account for more than $40 \%$ of the population in a given province (and zero otherwise) but it was never significant.

10 The development of roads is a priority for the World Bank that promoted the Rural Roads Project for South Sudan in 2012 in the amount of US\$38 million. The project will help to support the country's attempts to develop its untapped agricultural potential to improve the livelihood of the rural population, reduce food insecurity, improve basic services delivery and ensure peace. The
} 
interactive term State capital dummy*distance, where Distance measures how far is in $\mathrm{km}$ the State capital from Juba. This variable is equal to zero for non-state capital counties, and equal to a positive number otherwise. The larger the value of this interactive term, the more distant the state capital county is from the country capital. The rationale for this instrument is twofold: first, a state capital is the core of local administration, providing the headquarter with some already existing networks that facilitate the execution of the mission; secondly, infrastructures and international communication networks are more developed in Juba, therefore it is easier to transfer and manage troops around its area.

Figures 3 to 6 map the distribution of our dependent variable, cereal production. The reference point is the group dark yellow, which indicates the median counties: $50 \%$ of counties produce more than them, and 50\% produce less. Accordingly, the light green group has $10 \%$ of counties producing less than them and $90 \%$ of counties performing better than them. The interpretation of the other groups is similar. The figures show that that cereal production is quite erratic over the years; the median production level experiences a dramatic fall in 2009 (-38\%), followed by a recovery in $2010(+25 \%)$ and again a decrease in 2011 (-20\%). Furthermore, it is difficult to identify areas that are systematically more productive than others.

[Figure 3 about here]

[Figure 4 about here]

[Figure 5 about here]

[Figure 6 about here]

\section{Results}

support will help respond to the development challenges by providing reliable access to high agricultural production areas and enhancing agricultural marketing. The project will help the rural population in the project area to have access to market, employment opportunities, and to social and administrative services. 
Table 3 presents the results from the IV estimation of Equation 1. Continuous variables are expressed in logs; therefore the coefficients are interpreted as marginal effects. Moreover, all the specifications include regional dummies to control for unobserved heterogeneity, and year dummies to capture the effect of time. The fit of the models is always very high, with a $R^{2}$ of about 0.9 . The number of observations is limited to 233 because of missing data.

[Table 3 about here]

Before commenting the results, it is important to notice that the IV diagnostics support our specification. Both under-identification ${ }^{11}$ and overidentification $^{12}$ are always rejected, and indicate that we are using a suitable specification and that our instruments are valid. The same conclusion is drawn by observing the coefficients of the first stage regressions in Appendix A.2: except for the models 8 and 10 where also Killings is significant, our two instruments are the unique determinants of Blue Helmets.

The coefficients of Table 3 are consistent across the six models, and the main result is that, ceteris paribus, we find a significantly positive effect of the UN troops on cereal production. The coefficient indicates that a $1 \%$ increase in the ratio brings about an increase of cereal production of about $0.6 \%$. In other words, if we assume a net cereal production of 10,000 tonnes and the presence of 100 Blue Helmets, a $10 \%$ increase in the size of the troop allows the production of additional 600 tonnes. The coefficient associated to the labour-related variable, Population, is always negative as expected. As the number of individuals, keeping the harvested surface constant, the less fertile becomes the land, and the less efficient is the use of the soil. An increase (decrease) of the cultivated land, Total cereal area, on the other hand, increases (decreases) the output by a factor larger than one, verifying the

11 The null hypothesis of the Kleibergen-Paap rk LM statistic is that the model is under-identified.

12 The null hypothesis of the Hansen $\mathrm{J}$ test is that the model is not over-identified. 
predictions. Interestingly, the results find increasing returns to scale in the use of land in our dataset. Rainfall is positively associated to the crops, but its significance level is not robust across the models. The suspected non linearity, moreover, is nor verified. This results is probably justified by the very low degree of precipitations in the country.

The ethnicity dummies, Ethnicity and Dinka, are not significant but always negative. Although the Dinka tribe is devoted to agriculture and sheep farming, it is the dominant ethnic group in the country and this 'governmental' status might generate tension with the other groups, negatively affecting the harvest.

The Killings variable is not significant as well, and negative as expected. A larger number of conflict-related victims increases insecurity and discourages the agricultural activity. Nonetheless, we must note that the incidence of killings is very limited, ranging from 0 to 3.6 per thousands of inhabitants, reducing the significance of its coefficient. Furthermore, insecurity is affected also by armed raids that cause injured, refugees, loss of livestock and dwellings destruction, whose impact is not captured by Killing. Finally, the year dummies are highly significant and, consistently with official data from NBS, indicate that if compared to 2011, production was higher in both 2009 and 2010.

\section{Conclusions}

This paper empirically tested the hypothesis that UN troops contributed to secure crops in South Sudan during the period 2008-2011. We use an original dataset including all the 78 South Sudanese counties and estimate an augmented cereal production function that includes the Blue Helmets as an independent variable. We control for the non-random assignment of UN troops through an Instrumental Variables approach, and find the expected beneficial effect of the deployment of UN troops on agricultural output. The coefficient associated to the variable of interest in fact indicates a marginal effect of about $0.6 \%$. In other words, if we assume a net cereal production of 10,000 tonnes and the presence of 100 Blue Helmets, a $10 \%$ 
increase in the size of the troop allows the production of additional 600 tonnes. This effect is non-negligible in the light of the widespread food insecurity that strikes the country and the dependence from food imports of the whole region.

Drawing on the literature in political economy, we claim that this increase happens because of two channels of transmissions. Peacekeeping provides security at two different levels: at the micro level reducing conflict it lowers the risk of expropriation from militia groups at the level of the individual farmer, at the macro level it provides some public goods that are needed in order to escape from state fragility, such as governance, enforcement of contracts which are non-rival and nonexcludable in nature. These features are conducive to the restart of productive activities that were halted during the conflict.

Our results suggest that beside the usual humanitarian and political reasons behind peacekeeping, we should also consider an economic role for these missions in evaluating their costs and benefits.

The analysis developed in this paper is the first empirical evaluation of the performance of UN troops in South Sudan, and the results are possibly idiosyncratic to the characteristics of this country. Future research is called to test the same hypothesis in different environments and answer to the more general question: do conflict-reducing policies actually improve the economic performance of a country afflicted by violence and insecurity? 


\section{REFERENCES}

Amara, J. (2012). Implications of Military Stabilization Efforts on Economic Development and Security: The Case of Iraq, Journal of Development Economics, 99, 244-254.

Arenas-García, N. (2010). The UNMIS in South Sudan: Challenges \& Dilemmas, Institute of Studies on Conflicts and Humanitarian Action, Documento $\mathrm{n}$. 5/2010, Madrid.

Arrow K., (1994). International Peacekeeping Forces: Economics and Politics, in Chatterji M., Jager H., Rima A. (eds.), The Economics of International Security, Essays in Honour of Jan Tinbergen. St. Martin's Press, New York.

Arrow K., (1995), Some General Observations on the Economics of Peace and War, Peace Economics, Peace Science, and Public Policy, vol. 2, n. 2, pp. 1-8.

Besley, T. and Ghatak, M (2009). Property rights and economic development, In: Rodrick, D. and Rosenzweig, M. R., (eds.) Handbook of Development Economics. Elsevier,

Bove, V., (2011), A Theoretical approach to the demand and supply of peacekeeping, The Economics of Peace and Security Journal, vol. 6, n.2, pp. 26-33.

Bove, V., Elia L., (2011), Supplying Peace: Participation in and troop contribution to peacekeeping missions, Journal of Peace Research, vol. 48, n.6, pp. 699-714.

Bove, V. and Smith, R. (2011). The Economics of Peacekeeping, in: D.L. Braddon and Hartley, K. (eds.) Handbook on the Economics of Conflict, Edward Elgar, Cheltenham.

Brauer J., Caruso R., (2013), Economists and Peacebuilding, in R. Mac Ginty (ed.), Handbook of Peacebuilding, Routledge, London, ch.11. pp. 147-158.

Carnahan, M., Durch W. and Gilmore S. (2006). The Economic Impact of Peacekeeping, The Peace Dividend Trust, New York.

Carnahan, M., Durch W. and Gilmore S., (2007), New data on the economic impact of UN peacekeeping, International Peacekeeping, vol. 14, n.3, 384-402. 
Caruso, R. (2010). On the Nature of Peace Economics, Peace Economics, Peace Science and Public Policy, vol. 16, n.2, art.2

Centre for International Governance Innovation (CIGI) (2011). Security Sector Reform Monitor: Southern Sudan, nr. 4/2011. Available at: http: / / www.cigionline.org / publications / 2011/ 1/ security-sector-reformmonitor-southern-sudan

Chowdhury A.R., Murshed S.M. (2013), A Note on War and Fiscal Capacity in Developing Countries, Peace Economics Peace Science and Public Policy, 19,3, 431-435.

Dixit, A. (2009). Governance Institutions and Economic Activity. American Economic Review, 99: 5-24.

DPKO (2012). Peacekeeping Fact Sheet. Available at: http://www.un.org/en/peacekeeping/resources/statistics/factsheet.shtml

Dorussen H., (2014), Peacekeeping works, or Does it?, Peace Economics Peace Science and Public Policy, 20, 4, 1-11

Dorussen H., Gizelis I., (2013), Into the lion's den: Local responses to UN peacekeeping. Journal of Peace Research 50: 691-706

FAO/WFP (2012). Crop and Food Security Assessment Mission to South Sudan Special Report 2012. Available at: http://www.fao.org/docrep/015/al984e/al984e00.pdfGaibulloev, K., Sandler, T. and Shimizu, H (2009). Demands for UN and Non-UN Peacekeeping: Nonvoluntary versus Voluntary Contributions to a Public Good, Journal of Conflict Resolution, 53: 827-852

Gleditsch, Kristian, Kyle Beardsley (2015), Peacekeeping as Conflict Containment. International Studies Review (forthcoming)

Isard, W., (1994), Peace Economics: A Topical perspective, Peace Economics, Peace Science, and Public Policy, vol. 1, n. 2, pp. 6-9.

Johnson, D.H. (2011). The Root Causes of Sudan's Civil Wars: Peace Or Truce, James Currey, Suffolk. 
Jyoti K., Sandler T., Shimizu H., (1999), The Demand for UN peacekeeping, 19751996, Kyklos, vol. 52, n.3, pp. 345-368.

Klein L.R., Marwah K., (1996), Economic Aspects of Peacekeeping Operations, Gleditsch N.P., Bjerkholt O., Cappelen A., Smith R.P., Dunne J.P., (eds.), The Peace Dividend, North-Holland, Amsterdam, ch. 27.

Lacher, W. (2012). South Sudan: International State-Building and Its Limits, German Institute for International Security Affairs, PR 4, Berlin.

Mc Evoy, C. and LeBrun E. (2010). Uncertain Future: Armed Violence in Southern Sudan, Graduate Institute of International and Development Studies, Geneva.

Metelits, C. (2004). Reformed Rebels? Democratization, Global Norms, and the Sudan People's Liberation Army, Africa Today, 51, 65-84.

Morrissey O., Willem te Velde D., Hewitt A., (2002), Defining International Public Goods: Conceptual Issues, in Ferroni M., Mody A., (eds.) International Public Goods: Incentives, Measurement and Financing, pp. 31-46. Kluwer, Boston.

Oakland Institute (2011). Understanding Land Investment Deals in Africa. Country Report: South Sudan. Available at: http: / / www.oaklandinstitute.org / understanding-land-investment-deals-africasouth-sudan.

RSS Minister of Agriculture (2011). South Sudan: the World Newest Investment Destination, presented at the Agribusiness Forum 2011. Available at: http: / / www.oaklandinstitute.org / sites / oaklandinstitute.org / files / SouthSuda nAgribusinessPotential_Oct2011.pdf

Rolandsen, O.H. (2009). Land, Security, and Peace Building in the Southern Sudan, International Peace Research Institute (PRIO), Oslo.

Ruggeri, A., Gizelis T.I. and Dorussen, H. (2013). Managing Mistrust: An Analysis of Cooperation with UN Peacekeeping in Africa, Journal of Conflict Resolution, $57,3,1-23$

Sandler T., Shimizu H., (2003), Nato Peacekeeping and Burden Sharing: 1994-2000, Public Finance Review, vol. 31, n.2, pp. 123-143 
Sandler T., (2002), Financing International Public Goods, in Ferroni M. and Mody A. (eds.), International Public Goods, Incentives, Measurement and Financing, pp. 81-114, Kluwer, Boston.

Solomon, B. (2007). Political Economy of Peacekeeping. Handbook of Defence Economics: Defence in a Globalized World. Amsterdam: North-Holland, 741774 .

South Sudan Monitor (2011). UNMISS: A Second Chance for UN Peacekeeping in South Sudan, available at: http: / / www.saferworld.org.uk/downloads / pubdocs / SSMAug2011.pdf

Tinbergen J., (1994), What is Peace Economics? Peace Economics, Peace Science and Public Policy, vol. 1, n.4, pp. 3-5

United Nations (2011b) Security Council Resolution 1996 (2011), available at: http: / / www.securitycouncilreport.org / atf/cf/\%7B65BFCF9B-6D27-4E9C8CD3-CF6E4FF96FF9\%7D/Sudan\%20SRES\%201996.pdf

United Nations (2011a). Special report of the Secretary-General on the Sudan, http:/ / www.un.org/ga / search / view_doc.asp? symbol=S / 2011/314

UNMISS (2011a) UNMISS Mandate, available at: http: / / www.un.org / en / peacekeeping / missions / unmiss / mandate.shtml.

UNMISS (2011b). UNMISS Headquarters internal reports, Juba, South Sudan.

William, P.D. (2011). Horn of Africa: Webs of Conflict and Pathways to Peace, Woodrow Wilson International Centre for Scholars, Washington.

World Bank (2013). South Sudan - Interim strategy note for FY2013-2014. Washington D.C.: The World Bank. http://documents.worldbank.org/curated/en/2013/01/17234245/south-sudaninterim-strategy-note-fy2013-2014 
Table 1 - Data description and sources

\begin{tabular}{|c|c|c|}
\hline Variable & Description & Source \\
\hline Cereal & Net cereal production in tonnes & Statistical Yearbook, NBS. Years 2009-2011 \\
\hline Blue Helmets & Number of UN soldiers physically stationed in the county & OCHA in Juba \\
\hline Households & Number of households in the county & Statistical Yearbook, NBS. Years 2009-2011 \\
\hline Share farming households & $\begin{array}{l}\text { Share of farming households on the total number of } \\
\text { households }\end{array}$ & Statistical Yearbook, NBS. Years 2009-2011 \\
\hline Ethnicity & $\begin{array}{l}\text { Dummy }=1 \text { if the county is multi-ethnical, dummy=0 } \\
\text { otherwise }\end{array}$ & OCHA in Juba \\
\hline Killing & $\begin{array}{l}\text { Number of conflict-related deaths per thousands of } \\
\text { individuals }\end{array}$ & OCHA in Juba, and www.sudantribune.com \\
\hline Population & Population size & Statistical Yearbook, NBS. Years 2009-2011 \\
\hline 2011 dummy & Dummy $=1$ if year $==2011$, dummy $=0$ otherwise & Own calculations \\
\hline Rain & Average rainfall & World Food Program (WFP) and NBS \\
\hline $\begin{array}{l}\text { State capital } \\
\text { Dummy }\end{array}$ & $\begin{array}{l}\text { Dummy }=1 \text { if the county is a state capital, dummy=0 } \\
\text { otherwise }\end{array}$ & Statistical Yearbook, NBS. Years 2009-2011 \\
\hline Distance from Juba & $\mathrm{Km}$ distance from the county capital to the state capital & Statistical Yearbook, NBS. Years 2009-2011 \\
\hline
\end{tabular}


Table 2. Descriptive statistics

\begin{tabular}{lccccc}
\hline Variable & Obs. & Mean & Std. Dev. & Min & Max \\
\hline Cereal & 312 & $9,016.43$ & $9,176.51$ & 0 & 79,976 \\
Blue Helmets & 390 & 64.39 & 223.43 & 0 & 1,271 \\
Population & 386 & $107,199.4$ & $65,991.44$ & 10,077 & 397,594 \\
Surface area & 389 & $7,489.06$ & $5,584.14$ & 737.7 & $33,273.2$ \\
Rainfall & 312 & 8.57 & 2.17 & 4 & 13 \\
Ethnicity & 390 & 0.65 & 0.48 & 0 & 1 \\
Dinka dummy & 390 & 0.33 & 0.47 & 0 & 1 \\
Killing/thousand population & 311 & 0.20 & 0.51 & 0 & 3.63 \\
Total cereal area & 234 & $10,986.31$ & $7,412.51$ & 681 & 33,908 \\
Bahr-el-Ghazal dummy & 390 & 0.28 & 0.45 & 0 & 1 \\
Equatoria dummy & 390 & 0.31 & 0.46 & 0 & 1 \\
Roads & 390 & 1.21 & 0.90 & 0 & 4 \\
Distance from Juba & 390 & 560.54 & 265.15 & 0 & 1,070 \\
State capital & 390 & 0.13 & 0.33 & 0 & 1 \\
State capital*distance & 390 & 61.65 & 189.27 & 0 & 834 \\
\hline
\end{tabular}


Table 3. Second stage estimation of Equation 1

\begin{tabular}{|c|c|c|c|c|c|c|c|c|c|c|c|}
\hline Dep. Var: $\ln$ Cereal & (1) & (2) & (3) & (4) & (5) & (6) & (7) & (8) & (9) & $(10)$ & $(11)$ \\
\hline Ln Blu Helmets & $\begin{array}{c}0.007^{*} \\
(0.003)\end{array}$ & $\begin{array}{c}0.007 * * \\
(0.003)\end{array}$ & $\begin{array}{c}0.007 * * \\
(0.003)\end{array}$ & $\begin{array}{c}0.006^{* *} \\
(0.003)\end{array}$ & $\begin{array}{l}0.006^{*} \\
(0.003)\end{array}$ & $\begin{array}{l}0.006^{*} \\
(0.003)\end{array}$ & $\begin{array}{c}0.006^{* *} \\
(0.003)\end{array}$ & $\begin{array}{l}0.006^{*} \\
(0.003)\end{array}$ & $\begin{array}{l}0.006^{*} \\
(0.003)\end{array}$ & $\begin{array}{l}0.006^{*} \\
(0.003)\end{array}$ & $\begin{array}{l}0.006^{*} \\
(0.003)\end{array}$ \\
\hline Ln Population & $\begin{array}{c}-0.268^{* * *} \\
(0.077)\end{array}$ & $\begin{array}{c}-0.285^{* * *} \\
(0.075)\end{array}$ & $\begin{array}{c}-0.279 * * * \\
(0.066)\end{array}$ & $\begin{array}{c}-0.264^{* * * *} \\
(0.068)\end{array}$ & $\begin{array}{c}-0.266^{* * * *} \\
(0.079)\end{array}$ & $\begin{array}{c}-0.266^{* * *} \\
(0.079)\end{array}$ & $\begin{array}{c}-0.265^{* * *} \\
(0.075)\end{array}$ & $\begin{array}{c}-0.261^{* * *} \\
(0.074)\end{array}$ & $\begin{array}{c}-0.267^{* * *} \\
(0.077)\end{array}$ & $\begin{array}{c}-0.263^{* * *} \\
(0.076)\end{array}$ & $\begin{array}{c}-0.262^{* * *} \\
(0.082)\end{array}$ \\
\hline Ln Rainfall & $\begin{array}{l}0.194^{*} \\
(0.104)\end{array}$ & & & $\begin{array}{c}0.114 \\
(0.099)\end{array}$ & $\begin{array}{c}0.039 \\
(0.061)\end{array}$ & $\begin{array}{l}0.025^{*} \\
(0.014)\end{array}$ & $\begin{array}{l}0.199 * \\
(0.102)\end{array}$ & $\begin{array}{c}0.201 * * \\
(0.100)\end{array}$ & $\begin{array}{l}0.190^{*} \\
(0.101)\end{array}$ & $\begin{array}{l}0.193^{*} \\
(0.100)\end{array}$ & $\begin{array}{l}0.196^{*} \\
(0.104)\end{array}$ \\
\hline Ln Rainfall 2 & & & & & $\begin{array}{l}-0.001 \\
(0.004)\end{array}$ & & & & & & \\
\hline Ln Total cereal area & $\begin{array}{c}1.229^{* * *} \\
(0.061)\end{array}$ & $\begin{array}{c}1.241^{* * *} \\
(0.059)\end{array}$ & $\begin{array}{c}1.106^{* * *} \\
(0.080)\end{array}$ & $\begin{array}{c}1.104^{* * *} \\
(0.080)\end{array}$ & $\begin{array}{c}1.227^{* * *} \\
(0.062)\end{array}$ & $\begin{array}{c}1.226^{* * * *} \\
(0.061)\end{array}$ & $\begin{array}{c}1.226^{* * *} \\
(0.059)\end{array}$ & $\begin{array}{c}1.224 * * * \\
(0.059)\end{array}$ & $\begin{array}{c}1.227 * * * \\
(0.061)\end{array}$ & $\begin{array}{c}1.225^{* * *} \\
(0.061)\end{array}$ & $\begin{array}{c}1.218^{* * *} \\
(0.069)\end{array}$ \\
\hline Ln Cereal, $t-1$ & & & $\begin{array}{c}0.139 * * * \\
(0.052)\end{array}$ & $\begin{array}{c}0.130 * * \\
(0.052)\end{array}$ & & & & & & & \\
\hline Bahr-el-Ghazal dummy & $\begin{array}{c}0.415^{* * *} \\
(0.066)\end{array}$ & $\begin{array}{c}0.428^{* * * *} \\
(0.067)\end{array}$ & $\begin{array}{c}0.366^{* * *} \\
(0.068)\end{array}$ & $\begin{array}{c}0.356^{* * *} \\
(0.068)\end{array}$ & $\begin{array}{c}0.412^{* * *} \\
(0.066)\end{array}$ & $\begin{array}{c}0.415^{* * *} \\
(0.066)\end{array}$ & $\begin{array}{c}0.415^{* * *} \\
(0.066)\end{array}$ & $\begin{array}{c}0.406^{* * *} \\
(0.066)\end{array}$ & $\begin{array}{c}0.433^{* * *} \\
(0.063)\end{array}$ & $\begin{array}{c}0.424^{* * *} \\
(0.064)\end{array}$ & $\begin{array}{c}0.420 * * * \\
(0.064)\end{array}$ \\
\hline Equatoria dummy & $\begin{array}{c}0.357 * * * \\
(0.044)\end{array}$ & $\begin{array}{c}0.371^{* * *} \\
(0.046)\end{array}$ & $\begin{array}{c}0.336^{* * *} \\
(0.045)\end{array}$ & $\begin{array}{c}0.320^{* * *} \\
(0.044)\end{array}$ & $\begin{array}{c}0.346^{* * *} \\
(0.055)\end{array}$ & $\begin{array}{c}0.342^{* * *} \\
(0.045)\end{array}$ & $\begin{array}{c}0.359^{* * *} \\
(0.049)\end{array}$ & $\begin{array}{c}0.347^{* * *} \\
(0.050)\end{array}$ & $\begin{array}{c}0.350^{* * *} \\
(0.046)\end{array}$ & $\begin{array}{c}0.339 * * * \\
(0.047)\end{array}$ & $\begin{array}{c}0.362^{* * *} \\
(0.045)\end{array}$ \\
\hline 2009 dummy & $\begin{array}{c}0.127 * * \\
(0.055)\end{array}$ & $\begin{array}{c}0.120 * * \\
(0.055)\end{array}$ & $\begin{array}{l}0.107^{*} \\
(0.055)\end{array}$ & $\begin{array}{c}0.110 * * \\
(0.055)\end{array}$ & $\begin{array}{c}0.127 * * \\
(0.055)\end{array}$ & $\begin{array}{c}0.126 * * \\
(0.055)\end{array}$ & $\begin{array}{c}0.127 * * \\
(0.055)\end{array}$ & $\begin{array}{c}0.119 * * \\
(0.055)\end{array}$ & $\begin{array}{l}0.127 * * \\
(0.055)\end{array}$ & $\begin{array}{c}0.120 * * \\
(0.055)\end{array}$ & $\begin{array}{c}0.127 * * \\
(0.055)\end{array}$ \\
\hline 2010 dummy & $\begin{array}{c}0.247 * * * \\
(0.042)\end{array}$ & $\begin{array}{c}0.263^{* * *} \\
(0.044)\end{array}$ & $\begin{array}{c}0.302^{* * *} \\
(0.045)\end{array}$ & $\begin{array}{c}0.293^{* * *} \\
(0.045)\end{array}$ & $\begin{array}{c}0.246^{* * *} \\
(0.042)\end{array}$ & $\begin{array}{c}0.246^{* * *} \\
(0.042)\end{array}$ & $\begin{array}{c}0.247 * * * \\
(0.042)\end{array}$ & $\begin{array}{c}0.238^{* * *} \\
(0.042)\end{array}$ & $\begin{array}{c}0.247 * * * \\
(0.042)\end{array}$ & $\begin{array}{c}0.239 * * * \\
(0.042)\end{array}$ & $\begin{array}{c}0.248^{* * *} \\
(0.042)\end{array}$ \\
\hline Ethnicity & & & & & & & $\begin{array}{c}-0.009 \\
(0.047)\end{array}$ & $\begin{array}{c}-0.008 \\
(0.047)\end{array}$ & & & \\
\hline Killing/thousand population & & & & & & & & $\begin{array}{c}-0.034 \\
(0.057)\end{array}$ & & $\begin{array}{l}-0.034 \\
(0.057)\end{array}$ & \\
\hline Dinka dummy & & & & & & & & & $\begin{array}{l}-0.032 \\
(0.053)\end{array}$ & $\begin{array}{l}-0.031 \\
(0.053)\end{array}$ & \\
\hline Ln surface area & & & & & & & & & & & $\begin{array}{c}0.021 \\
(0.031)\end{array}$ \\
\hline Constant & $\begin{array}{c}-0.120 \\
(0.633)\end{array}$ & $\begin{array}{c}0.083 \\
(0.629) \\
\end{array}$ & $\begin{array}{c}0.238 \\
(0.558) \\
\end{array}$ & $\begin{array}{c}0.006 \\
(0.568) \\
\end{array}$ & $\begin{array}{c}0.007 \\
(0.567) \\
\end{array}$ & $\begin{array}{c}0.068 \\
(0.568) \\
\end{array}$ & $\begin{array}{c}-0.144 \\
(0.623) \\
\end{array}$ & $\begin{array}{c}-0.162 \\
(0.621) \\
\end{array}$ & $\begin{array}{c}-0.106 \\
(0.620)\end{array}$ & $\begin{array}{l}-0.125 \\
(0.618) \\
\end{array}$ & $\begin{array}{c}-0.290 \\
(0.769) \\
\end{array}$ \\
\hline Observations & 233 & 233 & 232 & 232 & 233 & 233 & 233 & 233 & 233 & 233 & 233 \\
\hline $\mathrm{R}$-squared & 0.914 & 0.913 & 0.917 & 0.917 & 0.914 & 0.914 & 0.914 & 0.914 & 0.914 & 0.914 & 0.914 \\
\hline Underid test $p$-value & 0.004 & 0.004 & 0.004 & 0.004 & 0.004 & 0.004 & 0.006 & 0.005 & 0.006 & 0.006 & 0.003 \\
\hline Overid test $p$-value & 0.104 & 0.154 & 0.090 & 0.060 & 0.102 & 0.103 & 0.094 & 0.107 & 0.090 & 0.104 & 0.135 \\
\hline
\end{tabular}


Note: robust standard errors in parentheses. ${ }^{* *} p<0.01, * * p<0.05, * p<0.1$

Table 4. First stage estimation of Equation 1

\begin{tabular}{|c|c|c|c|c|c|c|c|c|c|c|c|}
\hline Dep Var: ln Blue Helmets & (1) & $(2)$ & (3) & (4) & (5) & (6) & (7) & (8) & (9) & (10) & (11) \\
\hline Ln Population & $\begin{array}{c}3.989 \\
(3.366)\end{array}$ & $\begin{array}{c}3.721 \\
(3.352)\end{array}$ & $\begin{array}{c}3.631 \\
(3.274)\end{array}$ & $\begin{array}{c}3.913 \\
(3.278)\end{array}$ & $\begin{array}{c}4.537 \\
(3.362)\end{array}$ & $\begin{array}{c}4.323 \\
(3.408)\end{array}$ & $\begin{array}{c}3.827 \\
(3.300)\end{array}$ & $\begin{array}{c}3.931 \\
(3.282)\end{array}$ & $\begin{array}{c}3.975 \\
(3.350)\end{array}$ & $\begin{array}{c}4.080 \\
(3.332)\end{array}$ & $\begin{array}{c}4.455 \\
(3.343)\end{array}$ \\
\hline Ln Surface area & & & & & & & & & & & $\begin{array}{c}1.661 \\
(1.080)\end{array}$ \\
\hline Ln Rainfall & $\begin{array}{c}5.521 \\
(4.555)\end{array}$ & & & $\begin{array}{c}6.955 \\
(4.777)\end{array}$ & & & $\begin{array}{c}4.923 \\
(4.494)\end{array}$ & $\begin{array}{c}4.843 \\
(4.506)\end{array}$ & $\begin{array}{c}5.621 \\
(4.513)\end{array}$ & $\begin{array}{c}5.573 \\
(4.520)\end{array}$ & $\begin{array}{c}5.410 \\
(4.443)\end{array}$ \\
\hline Ln Rainfall, t-1 & & $\begin{array}{c}4.668 \\
(4.596)\end{array}$ & $\begin{array}{c}6.210 \\
(4.789)\end{array}$ & & & & & & & & \\
\hline Ln Rainfall & & & & & $\begin{array}{l}-4.112 \\
(2.823)\end{array}$ & $\begin{array}{c}0.895 \\
(0.630)\end{array}$ & & & & & \\
\hline Ln Rainfall2 & & & & & $\begin{array}{c}0.291 \\
(0.178)\end{array}$ & & & & & & \\
\hline Ln Cereal, t-1 & & & $\begin{array}{c}-2.252 \\
(1.441)\end{array}$ & $\begin{array}{c}-2.285 \\
(1.432)\end{array}$ & & & & & & & \\
\hline Ln Total cereal area & $\begin{array}{l}-1.616 \\
(2.759)\end{array}$ & $\begin{array}{l}-1.416 \\
(2.736)\end{array}$ & $\begin{array}{c}0.755 \\
(2.767)\end{array}$ & $\begin{array}{c}0.566 \\
(2.793)\end{array}$ & $\begin{array}{l}-2.162 \\
(2.785)\end{array}$ & $\begin{array}{l}-1.842 \\
(2.781)\end{array}$ & $\begin{array}{l}-1.440 \\
(2.685)\end{array}$ & $\begin{array}{l}-1.510 \\
(2.683)\end{array}$ & $\begin{array}{l}-1.606 \\
(2.755)\end{array}$ & $\begin{array}{l}-1.679 \\
(2.749)\end{array}$ & $\begin{array}{l}-2.473 \\
(2.862)\end{array}$ \\
\hline Ethnicity & & & & & & & $\begin{array}{c}1.907 \\
(2.108)\end{array}$ & $\begin{array}{c}1.983 \\
(2.108)\end{array}$ & & & \\
\hline Dinka dummy & & & & & & & & & $\begin{array}{c}1.197 \\
(3.120)\end{array}$ & $\begin{array}{c}1.262 \\
(3.113)\end{array}$ & \\
\hline Killing/thousand population & & & & & & & & $\begin{array}{l}-1.218^{*} \\
(0.722)\end{array}$ & & $\begin{array}{c}-1.164^{*} \\
(0.686)\end{array}$ & \\
\hline Bahr-el-Ghazal dummy & $\begin{array}{l}-4.321^{*} \\
(2.337)\end{array}$ & $\begin{array}{l}-4.178^{*} \\
(2.344)\end{array}$ & $\begin{array}{l}-3.174 \\
(2.243)\end{array}$ & $\begin{array}{l}-3.270 \\
(2.240)\end{array}$ & $\begin{array}{l}-3.668 \\
(2.301)\end{array}$ & $\begin{array}{l}-4.564^{*} \\
(2.338)\end{array}$ & $\begin{array}{l}-4.404^{*} \\
(2.382)\end{array}$ & $\begin{array}{l}-4.650^{*} \\
(2.405)\end{array}$ & $\begin{array}{l}-4.965 \\
(3.570)\end{array}$ & $\begin{array}{l}-5.231 \\
(3.610)\end{array}$ & $\begin{array}{l}-3.877^{*} \\
(2.240)\end{array}$ \\
\hline Equatoria dummy & $\begin{array}{c}-1.464 \\
(2.334)\end{array}$ & $\begin{array}{l}-1.323 \\
(2.303)\end{array}$ & $\begin{array}{c}-0.759 \\
(2.222)\end{array}$ & $\begin{array}{c}-0.839 \\
(2.248)\end{array}$ & $\begin{array}{l}-3.897 \\
(2.658)\end{array}$ & $\begin{array}{l}-2.289 \\
(2.304)\end{array}$ & $\begin{array}{c}-2.101 \\
(2.431)\end{array}$ & $\begin{array}{c}-2.554 \\
(2.496)\end{array}$ & $\begin{array}{l}-1.241 \\
(2.245)\end{array}$ & $\begin{array}{l}-1.637 \\
(2.308)\end{array}$ & $\begin{array}{l}-1.065 \\
(2.306)\end{array}$ \\
\hline 2009 dummy & $\begin{array}{c}-0.178 \\
(0.375)\end{array}$ & $\begin{array}{c}-0.383 \\
(0.379)\end{array}$ & $\begin{array}{c}-0.163 \\
(0.418)\end{array}$ & $\begin{array}{c}0.107 \\
(0.437)\end{array}$ & $\begin{array}{c}-0.237 \\
(0.376)\end{array}$ & $\begin{array}{c}-0.166 \\
(0.376)\end{array}$ & $\begin{array}{c}-0.179 \\
(0.374)\end{array}$ & $\begin{array}{c}-0.444 \\
(0.436)\end{array}$ & $\begin{array}{c}-0.189 \\
(0.379)\end{array}$ & $\begin{array}{c}-0.443 \\
(0.439)\end{array}$ & $\begin{array}{c}-0.161 \\
(0.382)\end{array}$ \\
\hline 2010 dummy & $\begin{array}{l}-0.256 \\
(0.495)\end{array}$ & $\begin{array}{c}0.268 \\
(0.691)\end{array}$ & $\begin{array}{l}-0.357 \\
(0.751)\end{array}$ & $\begin{array}{l}-1.054 \\
(0.702)\end{array}$ & $\begin{array}{l}-0.306 \\
(0.495)\end{array}$ & $\begin{array}{l}-0.313 \\
(0.494)\end{array}$ & $\begin{array}{l}-0.249 \\
(0.493)\end{array}$ & $\begin{array}{c}-0.548 \\
(0.531)\end{array}$ & $\begin{array}{l}-0.263 \\
(0.498)\end{array}$ & $\begin{array}{l}-0.550 \\
(0.535)\end{array}$ & $\begin{array}{c}-0.164 \\
(0.505)\end{array}$ \\
\hline Roads & $\begin{array}{c}3.527^{* *} \\
(1.441)\end{array}$ & $\begin{array}{l}3.651^{* *} \\
(1.437)\end{array}$ & $\begin{array}{c}3.692^{* * *} \\
(1.396)\end{array}$ & $\begin{array}{l}3.561^{* *} \\
(1.403)\end{array}$ & $\begin{array}{c}3.494^{* *} \\
(1.456)\end{array}$ & $\begin{array}{c}3.407^{* *} \\
(1.438)\end{array}$ & $\begin{array}{c}3.823^{* *} \\
(1.474)\end{array}$ & $\begin{array}{c}3.888^{* *} \\
(1.480)\end{array}$ & $\begin{array}{l}3.608^{* *} \\
(1.419)\end{array}$ & $\begin{array}{c}3.663^{* *} \\
(1.424)\end{array}$ & $\begin{array}{c}3.650^{* *} \\
(1.421)\end{array}$ \\
\hline Statecap_dist & $\begin{array}{c}0.0283^{* * * *} \\
(0.008\end{array}$ & $\begin{array}{c}0.0284^{* * *} \\
(0.008)\end{array}$ & $\begin{array}{c}0.0284^{* * *} \\
(0.008)\end{array}$ & $\begin{array}{c}0.0283^{* * *} \\
(0.008)\end{array}$ & $\begin{array}{c}0.0278^{* * * *} \\
(0.008)\end{array}$ & $\begin{array}{c}0.0280 * * * \\
(0.008)\end{array}$ & $\begin{array}{c}0.0284^{* * *} \\
(0.008)\end{array}$ & $\begin{array}{c}0.0279 * * * \\
(0.008)\end{array}$ & $\begin{array}{c}0.0280 * * * \\
(0.008)\end{array}$ & $\begin{array}{c}0.0276^{* * *} \\
(0.008)\end{array}$ & $\begin{array}{c}0.0279 * * * \\
(0.008)\end{array}$ \\
\hline Constant & $\begin{array}{c}-64.48^{* *} \\
(26.60) \\
\end{array}$ & $\begin{array}{c}-61.91 * * \\
(27.11)\end{array}$ & $\begin{array}{c}-64.53^{* *} \\
(26.46) \\
\end{array}$ & $\begin{array}{c}-66.78^{* *} \\
(25.98) \\
\end{array}$ & $\begin{array}{l}-40.89 * \\
(24.13)\end{array}$ & $\begin{array}{c}-61.70 * * \\
(23.70) \\
\end{array}$ & $\begin{array}{c}-64.36^{* *} \\
(26.01)\end{array}$ & $\begin{array}{c}-64.15^{* *} \\
(25.92) \\
\end{array}$ & $\begin{array}{c}-64.99 * * \\
(26.37) \\
\end{array}$ & $\begin{array}{c}-64.82^{* *} \\
(26.28) \\
\end{array}$ & $\begin{array}{c}-76.68 * * * \\
(28.10) \\
\end{array}$ \\
\hline Observations & 233 & 233 & 232 & 232 & $25^{233}$ & 233 & 233 & 233 & 233 & 233 & 233 \\
\hline
\end{tabular}


R-squared

$0.466 \quad 0.463$

0.471

0.474

0.484

0.471

0.472

0.475

0.467

0.471

Note: robust standard errors in parentheses. ${ }^{* *} p<0.01, * * p<0.05,{ }^{*} p<0.1$ 
Figure 1. Presence of UN troops by county

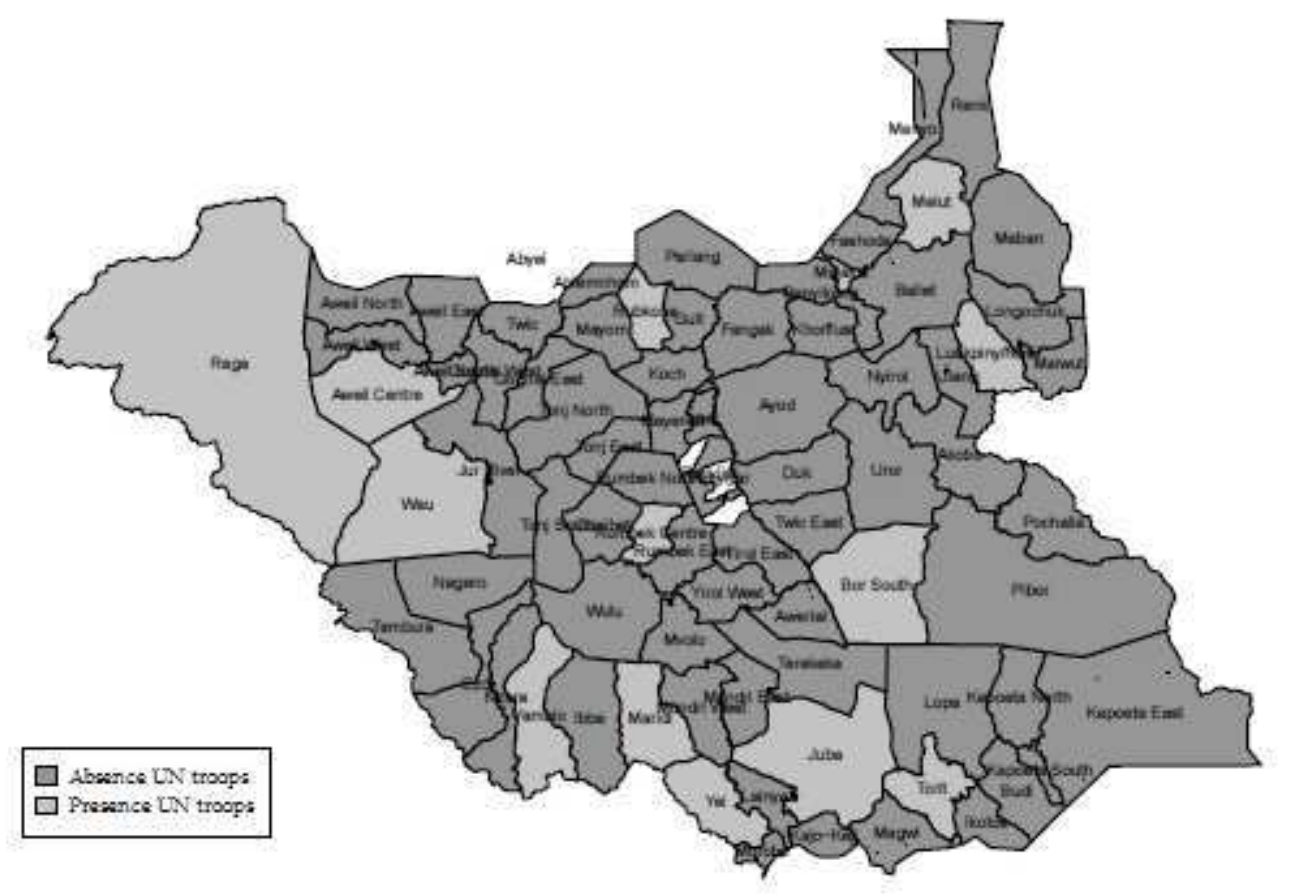

Source: Office of Coordination of Humanitarian Affairs (OCHA) in Juba.

Figure 2. Yearly deployment of UN troops by county

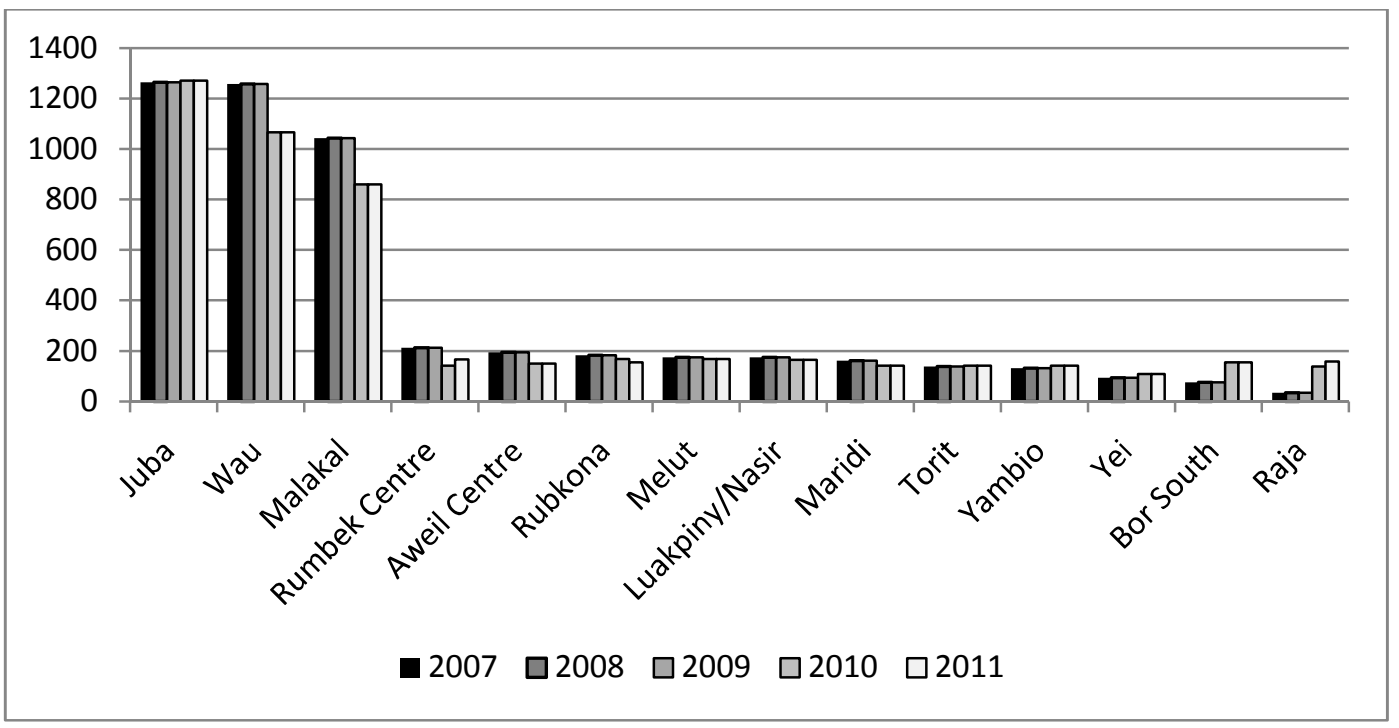

Source: Office of Coordination of Humanitarian Affairs (OCHA) in Juba. 
Figure 3 - Net cereal production by county, year 2008

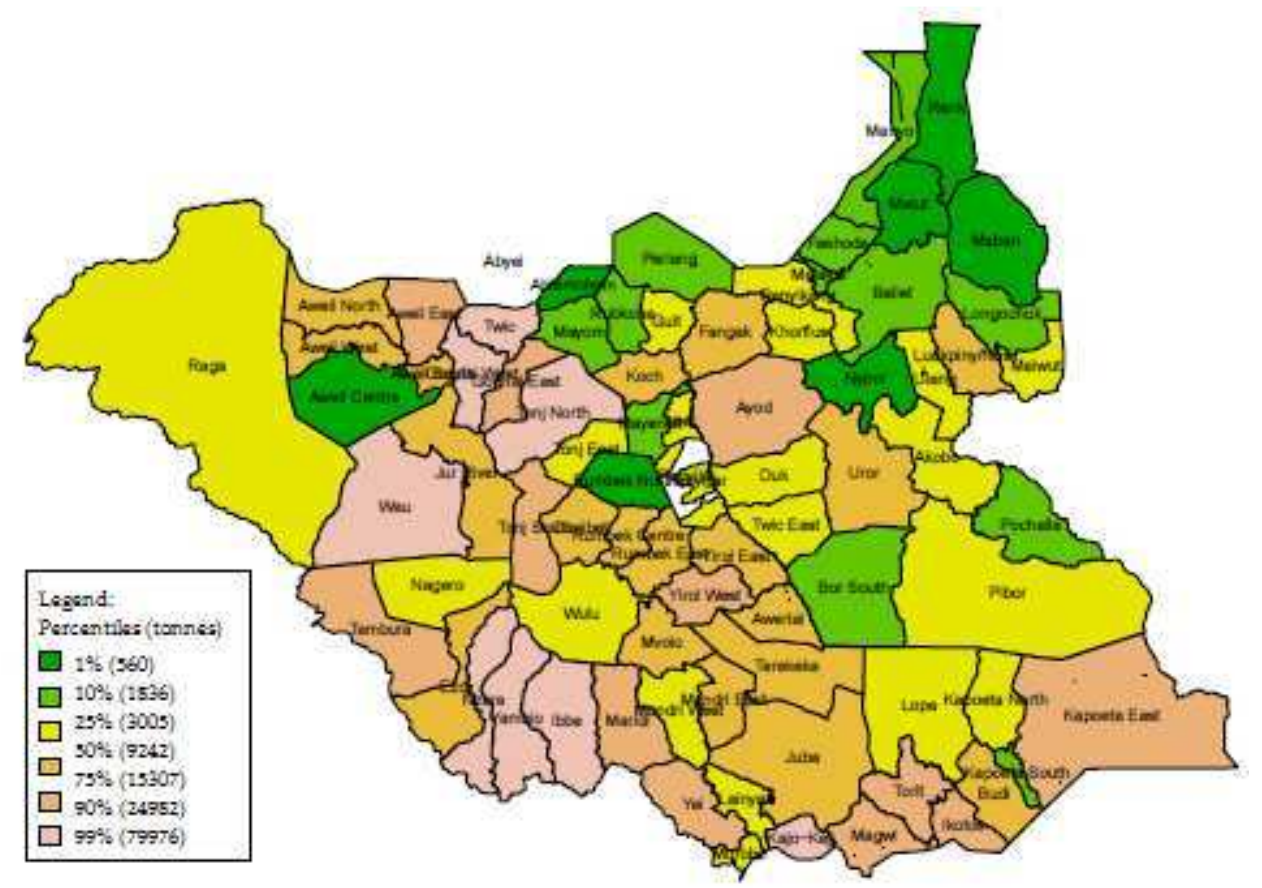

Source: South Sudan National Bureau of Statistics, NBS.

Figure 4 - Net cereal production by county, year 2009 


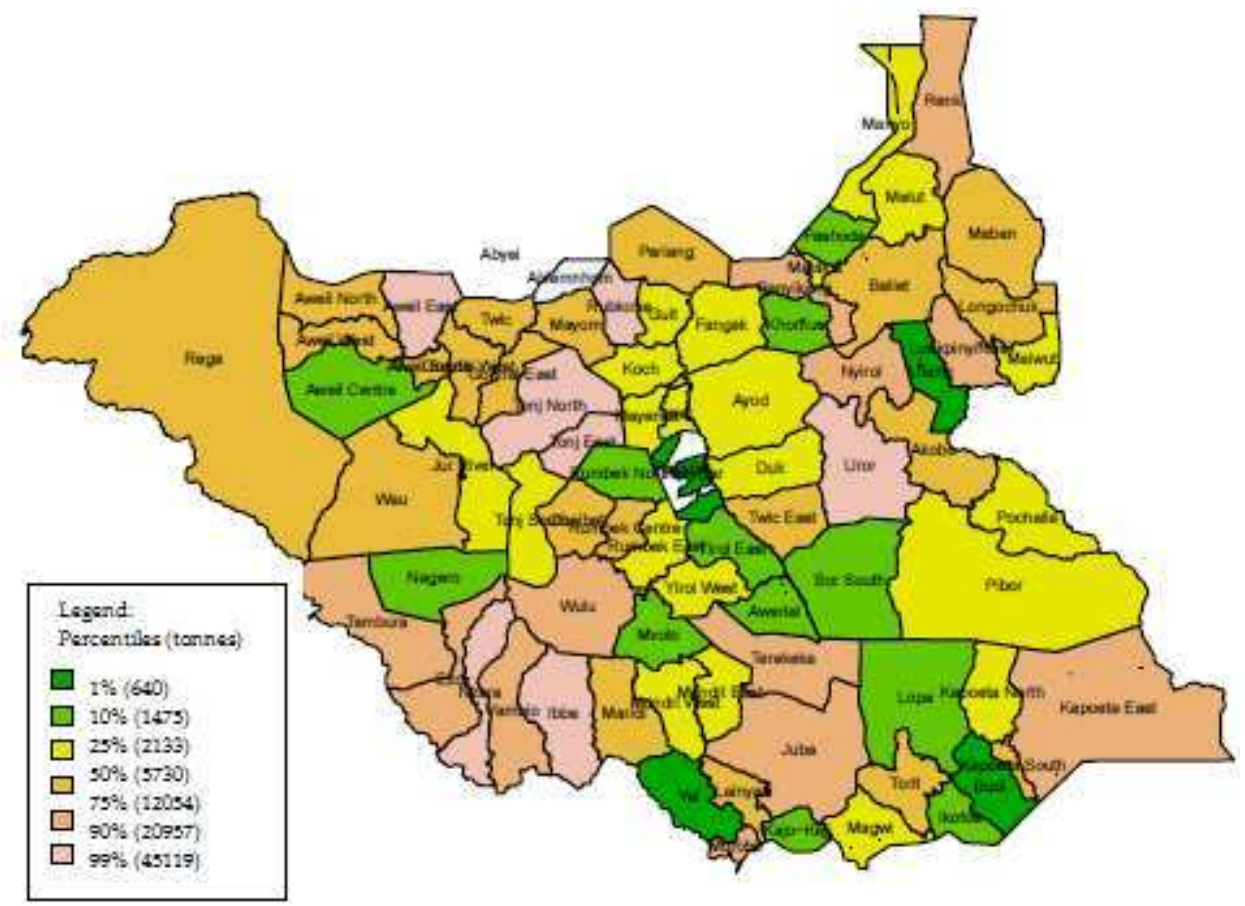

Source: South Sudan National Bureau of Statistics, NBS.

Figure 5 - Net cereal production by county, year 2010 


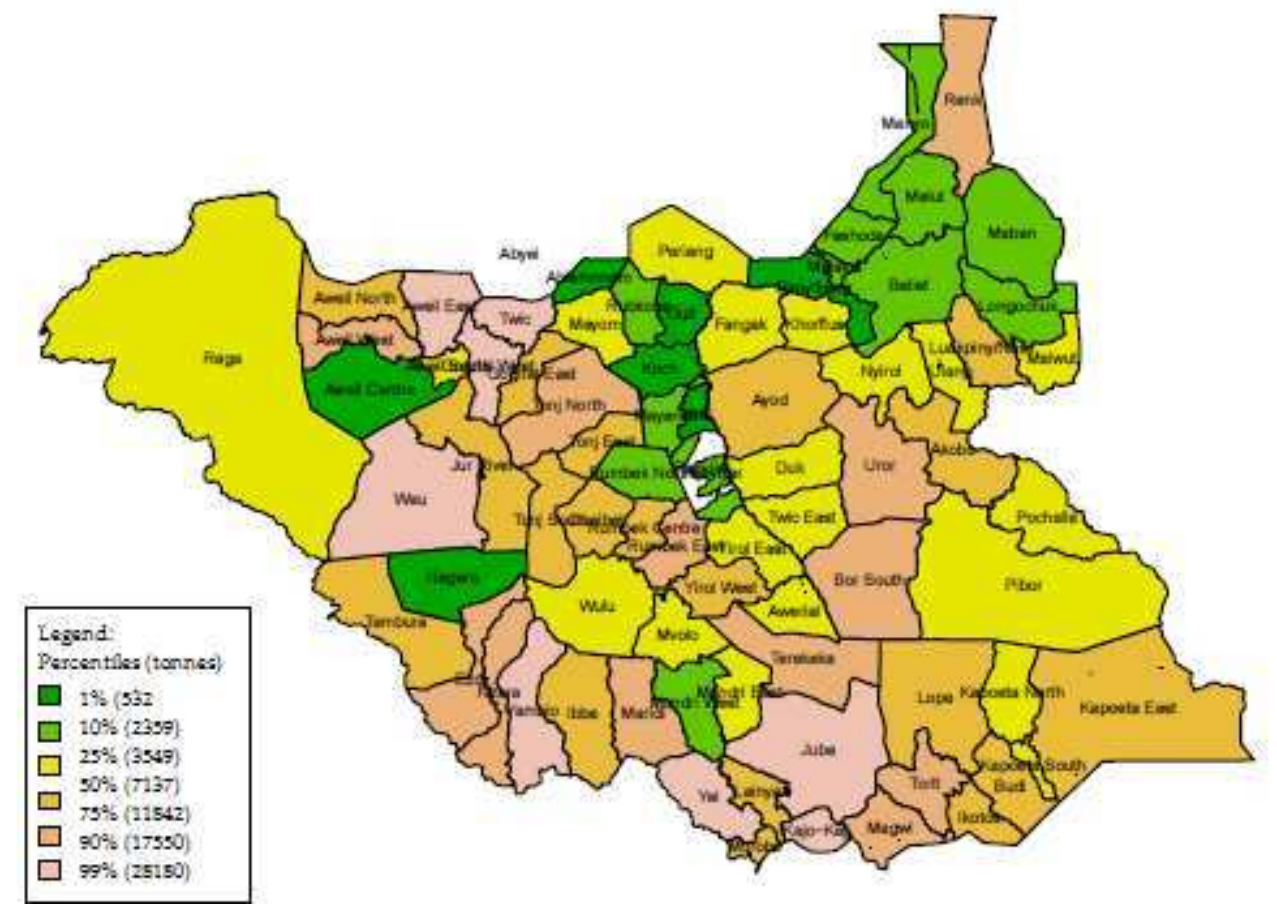

Source: South Sudan National Bureau of Statistics, NBS.

Figure 6 - Net cereal production by county, year 2011

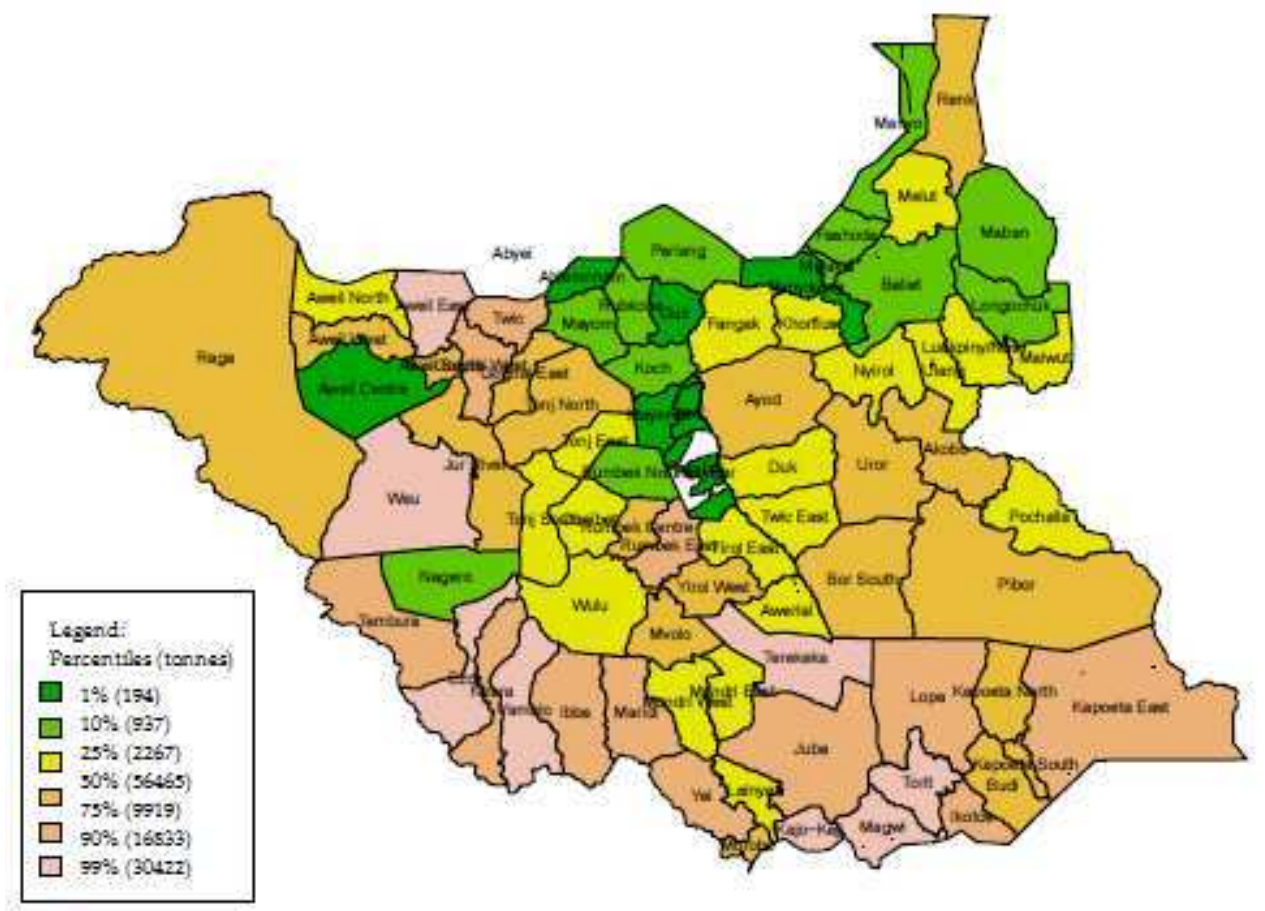

Source: South Sudan National Bureau of Statistics, NBS. 


\section{APPENDIX}

A.1 List of Regions, States and Counties of South Sudan

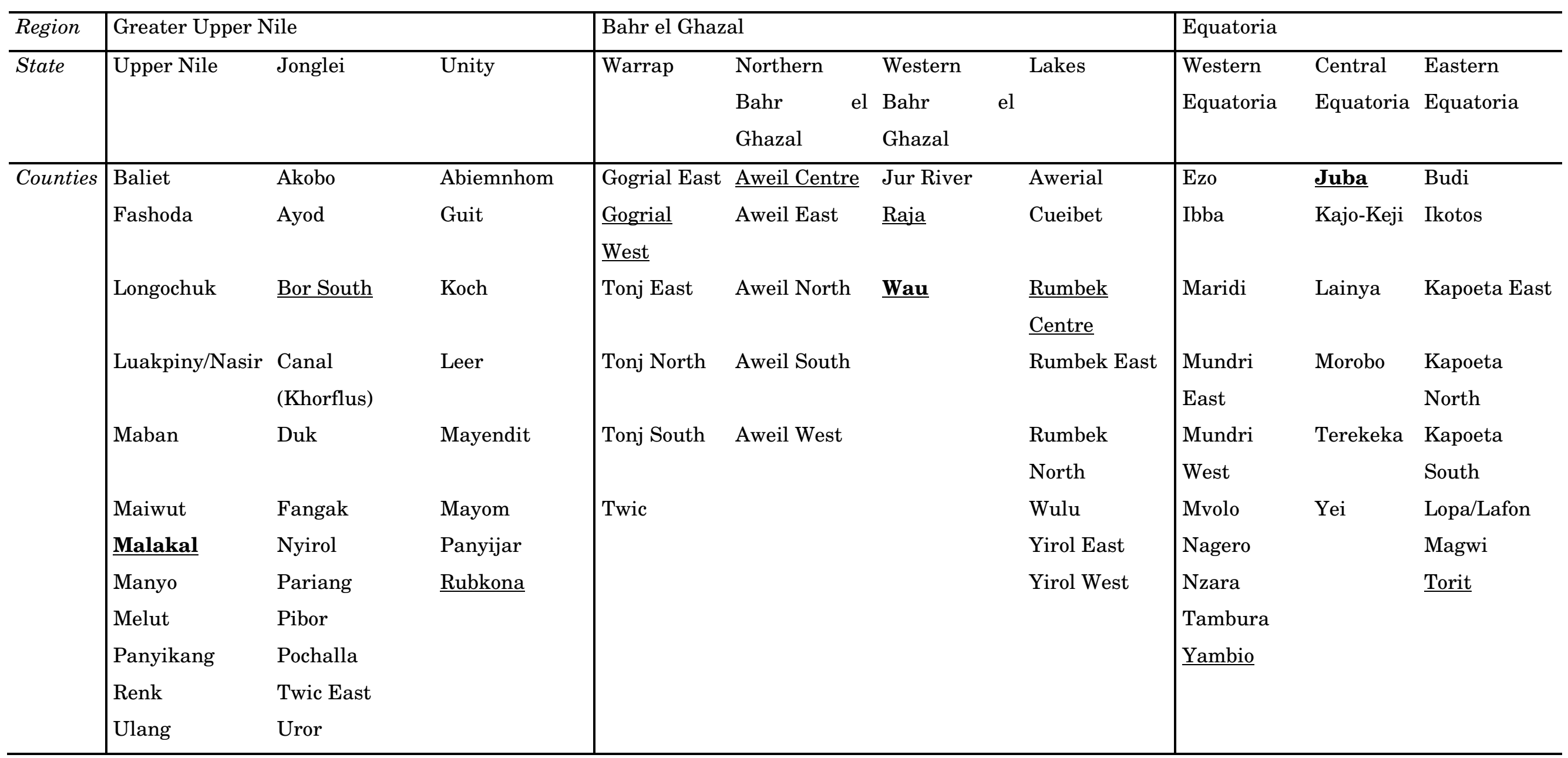

Note: Juba is the country capital; regional capitals are in bold, state capital are underscored. 